Article

\title{
Experimental Investigation of the Steam Ejector in a Single-Effect Thermal Vapor Compression Desalination System Driven by a Low-Temperature Heat Source
}

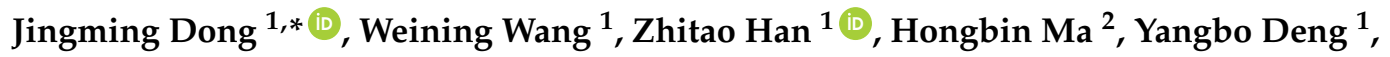 \\ Fengmin $\mathrm{Su}^{1}$ and Xinxiang Pan ${ }^{1}$ \\ 1 Institute of Marine Engineering and Thermal Science, Marine Engineering College, \\ Dalian Maritime University, Dalian 116026, China; wangweining@dlmu.edu.cn (W.W.); \\ hanzt@dlmu.edu.cn (Z.H.); dengyb@dlmu.edu.cn (Y.D.); fengminsu@dlmu.edu.cn (F.S.); \\ panxx@dlmu.edu.cn (X.P.) \\ 2 Department of Mechanical \& Aerospace Engineering, University of Missouri, Columbia, MO 65211, USA; \\ mah@missouri.edu \\ * Correspondence: dmudjm@dlmu.edu.cn; Tel.: +86-411-8472-5295
}

Received: 30 July 2018; Accepted: 30 August 2018; Published: 30 August 2018

\begin{abstract}
The paper presents an experimental investigation of a steam ejector in a single-effect thermal vapor compression (S-TVC) desalination system driven by a low-temperature (below $100{ }^{\circ} \mathrm{C}$ ) heat source. To investigate the performance of the steam ejector in the S-TVC desalination system, an experimental steam ejector system was designed and built. The influences of the nozzle exit position (NXP), operating temperatures, and the area ratio of the ejector (AR) on the steam ejector performance were investigated at primary steam temperatures ranging from $40{ }^{\circ} \mathrm{C}$ to $70{ }^{\circ} \mathrm{C}$, and at secondary steam temperatures ranging from $10^{\circ} \mathrm{C}$ to $25^{\circ} \mathrm{C}$. The experimental results showed that the steam ejector can work well in the S-TVC desalination system driven by a low-temperature heat source below $100{ }^{\circ} \mathrm{C}$. The steam ejector could achieve a higher coefficient of performance (COP) by decreasing the primary steam temperature, increasing the secondary steam temperature, and increasing the AR. The steam ejector could also be operated at a higher critical condensation temperature by increasing the primary steam temperature and secondary steam temperature, and decreasing the AR. This study will allow S-TVC desalination to compete with adsorption desalination (AD).
\end{abstract}

Keywords: desalination; single-effect thermal vapor compression (S-TVC); steam ejector; low-temperature heat source

\section{Introduction}

Human life and production are inseparable from fresh water, which only makes up $2.5 \%$ of the total water resources. With the rapid development of the world economy and the population explosion, the shortage of freshwater resources has become a growing global environmental problem. Desalination technology is deemed an effective means to solve the problem. It is the process of utilizing heat, electricity, and other energy, to separate the dissolved mineral salts, organisms, bacteria, viruses, and solids in seawater. Figure 1 shows the classification of seawater desalination technology based on the separation process. Multi-effect distillation (MED), multi-stage flash, and reverse osmosis are the commercial desalination technologies widely applied in the industry. Total global desalination capacity was around 74.8 million $\mathrm{m}^{3} / \mathrm{d}$ in $2011,63 \%$ of the total capacity was produced by reverse osmosis, $23 \%$ by multi-stage flash and $8 \%$ by MED [1]. However, every desalination technology consumes a lot of 
fossil fuel and emits large amounts of carbon dioxide. At present, global desalination plants produce 76 million tons of carbon dioxide per year, which is predicted to accelerate to 218 million tons per year by 2040 [2].

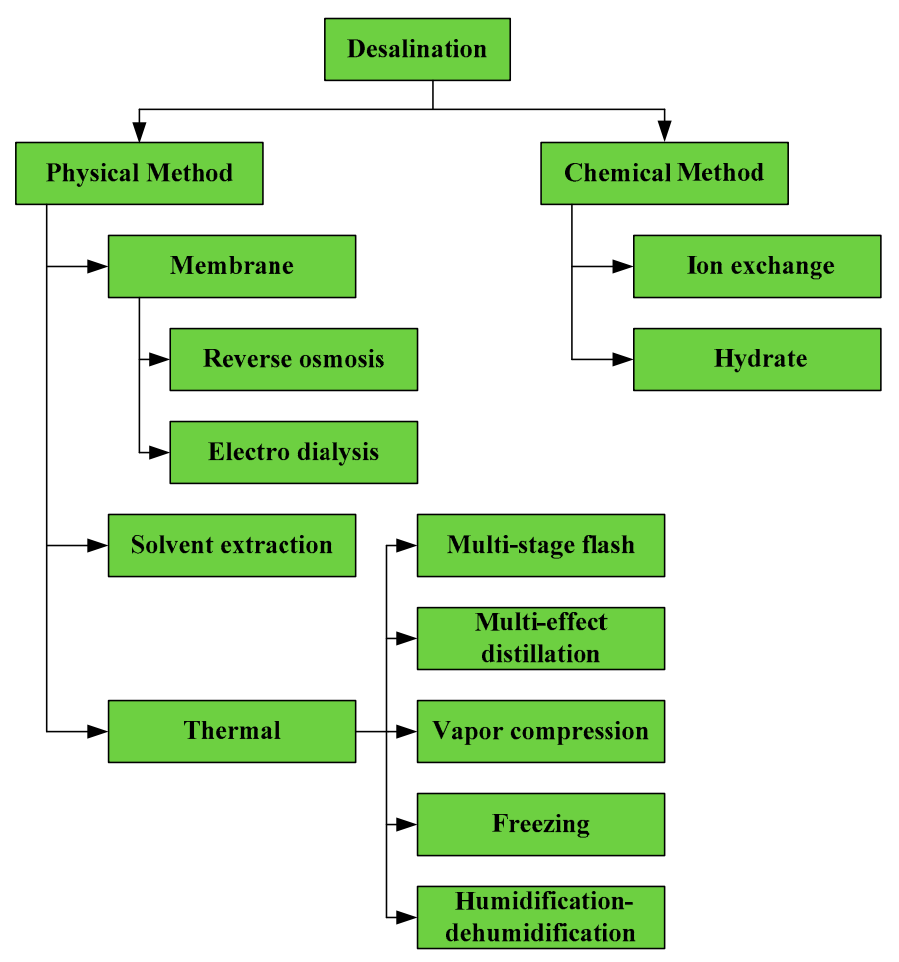

Figure 1. Classification of seawater desalination technology.

To overcome the disadvantages of traditional desalination technologies and further reduce carbon dioxide emissions, exploiting low-temperature heat sources below $100^{\circ} \mathrm{C}$ is a promising technology for the near future. Adsorption desalination (AD) can utilize low-temperature heat sources ranging from $50{ }^{\circ} \mathrm{C}$ to $85^{\circ} \mathrm{C}$, which is a method evolved from the adsorption refrigeration system. Silica-gel $[3,4]$ and zeolites $[5,6]$ have been utilized as adsorption media. Due to evaporation of seawater at temperatures below $35{ }^{\circ} \mathrm{C}$, scaling and corrosion are rare in the evaporator [7]. $\mathrm{Ng}$ and his collaborators [8-12] have made great contributions to the research and development of adsorption desalination. However, adsorbent performance decreases after being used for a period of time and control of the adsorber beds is complex. These problems greatly limit the development of its application. Single-effect thermal vapor compression (S-TVC) has a similar principle as that found in AD. S-TVC has greater development potential because of its effortless operation, low maintenance cost and simplicity in construction. The system is mainly composed of the primary evaporator, secondary evaporator, steam ejector and the condenser, as shown in Figure 2. When the system is started, the distilled water in the primary evaporator is heated by the heat source at temperatures ranging from $140{ }^{\circ} \mathrm{C}$ to $180^{\circ} \mathrm{C}$. A high-pressure and high-temperature primary steam $\left(M_{p}\right)$ generated in the primary evaporator enters the steam ejector and expands as it exits the nozzle. The low-pressure region produced by this expansion vaporizes and entrains a secondary steam $\left(M_{s}\right)$ from the secondary evaporator at a temperature of $T_{s}$. The two steam streams begin to mix in the steam ejector. After that, the mixed steam $\left(M_{p}+M_{s}\right)$ is condensed in the secondary evaporator, which provides heat to the secondary evaporator to generate steam $\left(M_{d w}\right)$. Meanwhile, the seawater $\left(M_{c w}+M_{f}\right)$ at a temperature of $T_{c w}$ is pumped into the condenser to condense the steam $\left(M_{d w}-M_{s}\right)$ into liquid. Then, the seawater is heated to $T_{f}$ from $T_{c w}$. Part of the seawater, as cooling water $\left(M_{c w}\right)$, is discharged. Another part of the seawater serves as feed seawater $\left(M_{f}\right)$, which is supplied to the secondary evaporator. Before entering the secondary 
evaporator, feed seawater must be pretreated. In the secondary evaporator, feed seawater is heated into steam $\left(M_{d w}\right)$ at temperatures ranging from $50{ }^{\circ} \mathrm{C}$ to $80^{\circ} \mathrm{C}$. Part of the steam, as secondary steam $\left(M_{s}\right)$, is entrained by the primary steam $\left(M_{p}\right)$. Another part of the steam $\left(M_{d w}-M_{s}\right)$ is condensed in the condenser. A known mass flow rate of fresh water $\left(M_{d w}\right)$ is produced. The remainder $\left(M_{p}\right)$ is pumped back to the primary evaporator, to complete a working cycle of the S-TVC.

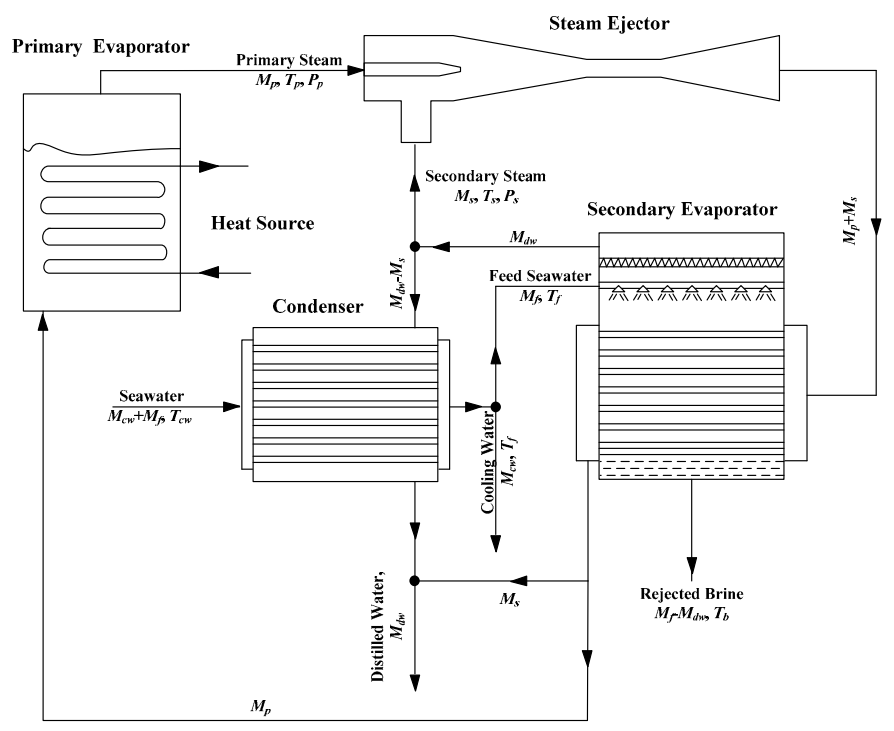

Figure 2. Schematic of a single effect thermal vapor compression desalination system.

The theoretical model of the S-TVC was developed by Al-Najem and El-Dessouky in 1997 [13]. El-Dessouky et al. [14] developed a steady-state model, which considered the changes of the physical properties with salinity and temperature, boiling-point elevation and pressure drop through the demister. Ji et al. [15] investigated the effects of the cooling water mass flow rate and the seawater inlet temperature on the performance of the system. Theoretical results showed that system performance decreases as the seawater inlet temperature deviates from the design value. Pilipovik and Riverol [16] evaluated the seasonal influence on the fouling deposition of the S-TVC unit by using the sequential annealing method. The steam ejector is a critical component of the S-TVC system.

The performance of the steam ejector has a great impact on the energy efficiency and the operation condition of the S-TVC system. However, there is little research on the steam ejector in the S-TVC. So far, the studies of the steam ejector in the thermal vapor compression (TVC) are often found in the multiple-effect distillation with thermal vapour compression (MED-TVC). Sharifi et al. [17] investigated the effect of the nozzle geometry on the performance of the steam ejector by using numerical simulations. Liu and his collaborators [18-23] investigated the effects of mixing chamber geometries, suction position, nozzle structures and auxiliary entrainment on the steam ejector performance in the MED-TVC with numerical simulation in their papers. Wang et al. [24,25] investigated the effect of the area ratio of the ejector (AR), surface roughness and superheat on condensation in the nozzle. Liu [26] investigated the AR on the ejector efficiencies and established empirical correlations to predict ejector efficiencies. Liu and Ji $[27,28]$ numerically investigated the flow characteristics inside the steam ejector, which could help to better understand the mechanism of steam ejector.

From the above, the steam ejector, whether in the S-TVC or in the MED-TVC, has not been investigated with low-temperature heat sources below $100{ }^{\circ} \mathrm{C}$. For now, S-TVC desalination cannot compete with AD. The main objective of this study is to explore the steam ejector in the S-TVC desalination system driven by low-temperature heat sources below $100{ }^{\circ} \mathrm{C}$. In this paper, the effects of operating temperatures, nozzle exit position (NXP) and AR on the performance of the steam ejector powered by a low-temperature heat source were experimentally investigated. 


\section{Experimental System}

To investigate the performance of the steam ejector driven by a low-temperature heat source, an experimental test system was established as shown in Figure 3. The experimental system was simplified to focus on the performance of the steam ejector. It mainly consists of an experimental ejector, a primary evaporator, a secondary evaporator, two electric heaters, two transformers, a condenser, a liquid storage tank, a circulating pump, and measuring devices. The experimental ejector mainly consists of four components: a diffuser, a constant area section, a mixing chamber and a nozzle with a mechanical adjusting mechanism. The mechanical adjusting mechanism can change the position of the nozzle exit in the mixing chamber of the experimental ejector. The diffuser, the constant area section, and the mixing chamber are connected by flanges. Figure 4 shows dimensions of the experimental ejector.

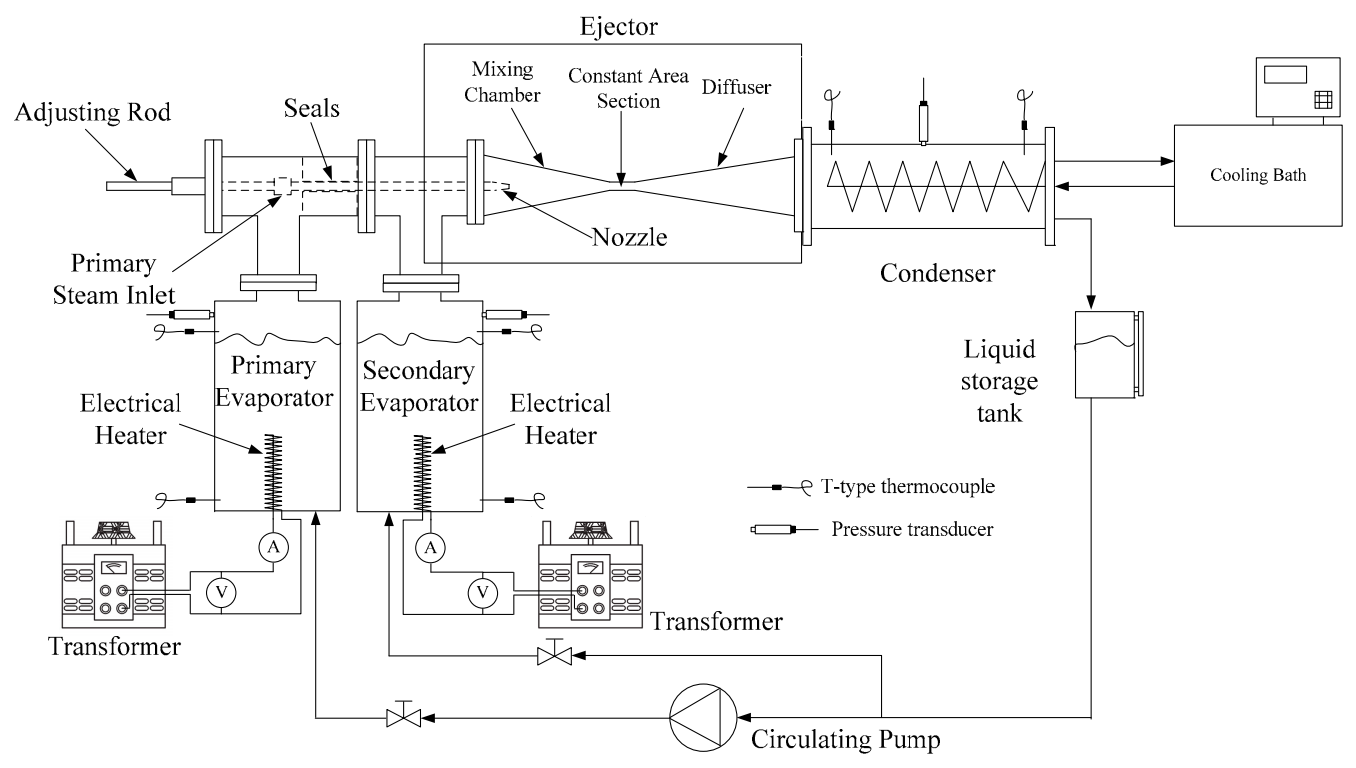

Figure 3. Schematic of the experimental system.

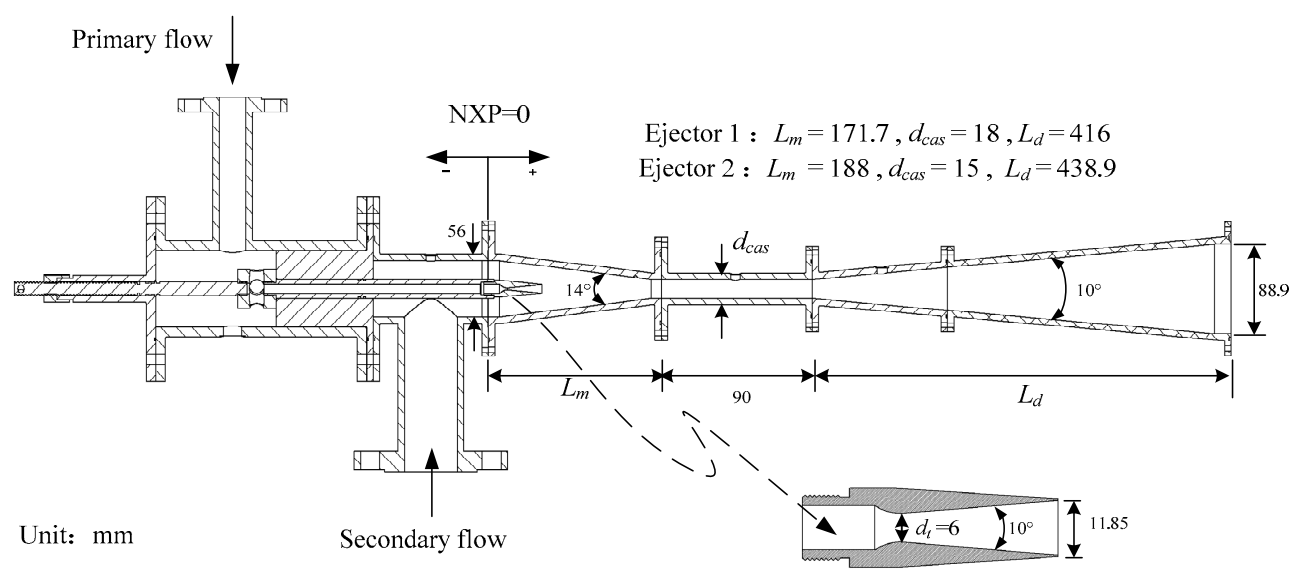

Figure 4. Dimensions of the experimental ejector and primary nozzle. NXP: nozzle exit position.

The primary evaporator and secondary evaporator are connected to the experimental ejector by the flanges welded on their top end. A 5-kW immersion electrical heater was installed at the bottom of the primary evaporator to simulate the low-temperature heat source in the primary evaporator. Another 5-kW immersion electrical heater was installed at the bottom of the secondary evaporator 
to simulate the thermal source in the secondary evaporator. Temperatures of the primary steam and secondary steam were adjusted by the electrical heaters in the primary evaporator and in the secondary evaporator, respectively. Two transformers were used to adjust the heating power of these two heaters. The accuracy for both the voltmeter and ammeter of the electrical heater was $\pm 0.1 \%$. Using good thermal insulating materials for the primary evaporator and secondary evaporator reduced heat loss. A shell and tube heat exchanger were used as the condenser. The temperature of the mixed steam in the condenser was controlled by changing the outlet temperature and the mass flow rate of the cooling water, which circulated in the cooling bath. The installation positions of type-T thermocouples $\left( \pm 0.5^{\circ} \mathrm{C}\right)$ and pressure transducers with an accuracy of $\pm 0.08 \%(0-5 \mathrm{kPa}$ for the secondary evaporator, $0-10 \mathrm{kPa}$ for the condenser and 0-100 kPa for the primary evaporator) are shown in Figure 3. The liquid storage tank was fabricated from a stainless steel cylinder with a level gauge. The circulating pump was an electrical diaphragm pump.

Deionized water served as the working medium. The primary evaporator and the secondary evaporator were filled with the deionized water before the experiment began. The working medium was then heated in the primary evaporator and secondary evaporator to remove the dissolved air. To verify the experimental results, the procedure mentioned above was repeated several times. For each test, the temperature in the primary evaporator was heated to the desired value. The steam ejector worked at a lower condensation temperature. At this time, the heating power of the electric heater in the secondary evaporator was adjusted by the transformer. Then, the secondary steam temperature in the secondary evaporator was observed. When the evaporation temperature was consistent with the desired value for more than $30 \mathrm{~min}$, we considered the system to be in equilibrium. All parameters, such as heating power inputs, temperatures and pressures, were recorded for an extra $20 \mathrm{~min}$ via a data acquisition system. The test was then repeated, but this time, the condensation temperature was increased by increasing the outlet temperature of the cooling water. The performance of the steam ejector is described by the coefficient of performance (COP), which is defined as the ratio between the electric power input to the secondary evaporator and the electric power input to the primary evaporator. The COP can be calculated according to the following equation:

$$
C O P=\frac{(V \times I)_{s}}{(V \times I)_{p}}
$$

\section{Results and Discussion}

According to the experimental test system shown in Figure 3 and the two ejectors shown in Figure 4, the steam ejector performance was determined under the condition of the primary steam temperature, which ranged from $40{ }^{\circ} \mathrm{C}$ to $70{ }^{\circ} \mathrm{C}$. The secondary steam temperature was set at $25^{\circ} \mathrm{C}$, $20^{\circ} \mathrm{C}, 15^{\circ} \mathrm{C}$ and $10^{\circ} \mathrm{C}$, in that order. These operating temperatures were selected according to studies of the AD $[3,12,29]$. The experimental results of the effects of the operating temperatures, NXP and AR on the performance of the steam ejector are summarized as follows.

At the beginning of the study, a tentative experiment was carried out with Ejector 1 . Figure 5 shows the experimental results at a primary steam temperature of $70{ }^{\circ} \mathrm{C}$ and a secondary steam temperature of $25^{\circ} \mathrm{C}$. It can be found that the COP remained constant at first and then declined rapidly with the increase of condensation temperature. When the COP began to decline, the steam ejector was at an unstable condition. The corresponding condensation temperature is called the critical condensation temperature, $T_{c}^{*}$. A further increase in the condensation temperature would cause the COP to rapidly decrease to zero. This is the operating characteristics of the steam ejector [17]. At that moment, the steam ejector could not function. The COP and critical condensation temperature are the most important performance parameters in the research of the steam ejector. From Figure 5, it is also observed that the COP was 0.59 and the critical condensation temperature was $35^{\circ} \mathrm{C}$. This illustrates that the steam ejector can operate in the S-TVC desalination system at a heat source temperature below $100^{\circ} \mathrm{C}$. 


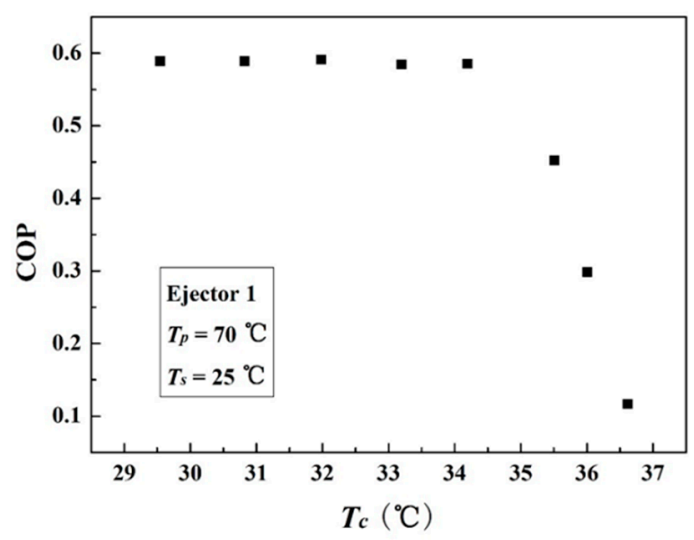

Figure 5. Effect of condensation temperature on the coefficient of performance (COP) of the steam ejector.

Figure 6 shows the COP variation in a steam ejector in response to the condensation temperature at different primary steam temperatures. As shown, the experimental results indicate that the steam ejector can operate when $T_{p}=40-70{ }^{\circ} \mathrm{C}$ and $T_{s}=25^{\circ} \mathrm{C}$, respectively. In Figure 6, it is found that the COP of the steam ejector decreases as the primary steam temperature increases. The COP could reach 2.64 when $T_{p}=40{ }^{\circ} \mathrm{C}$, which was about 4.5 times as high as that when $T_{p}=70^{\circ} \mathrm{C}$. It is also found that the critical condensation temperature increases as the primary steam temperature increases. The critical condensation temperature was only $22.5^{\circ} \mathrm{C}$ when $T_{p}=40^{\circ} \mathrm{C}$, which was about $12.5^{\circ} \mathrm{C}$ lower than when $T_{p}=70^{\circ} \mathrm{C}$. According to the experimental results, we draw the conclusion that the effect of the primary steam temperature on the COP and its effect on the critical condensation temperature are opposite. Increasing the primary steam temperature could result in a worse COP, but the steam ejector could then be operated at a higher critical condensation temperature. Considering the actual operation of the S-TVC desalination system, the critical condensation temperature should be a little higher than the secondary steam temperature. According to the experimental results shown in Figure 6, when the primary steam temperature is above $55^{\circ} \mathrm{C}$, the critical condensation temperature is higher than $25^{\circ} \mathrm{C}$, which is practical for the system.

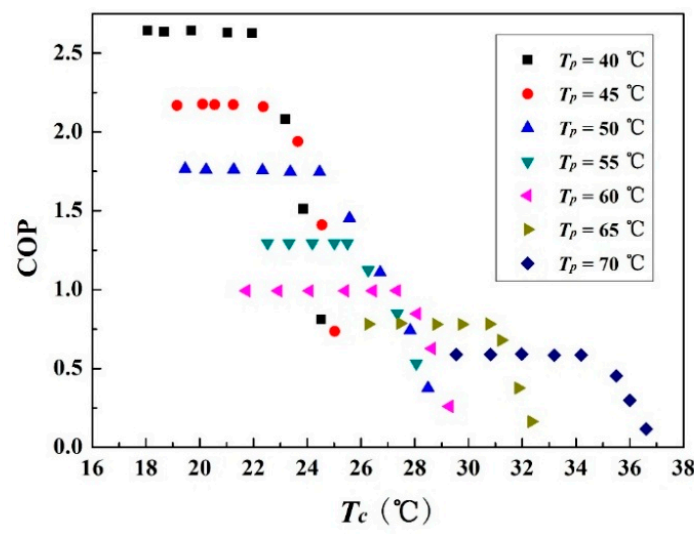

Figure 6. The effect of primary steam temperature on the COP of the steam ejector.

Figure 7 shows the comparison results of the steam ejector's COP at secondary steam temperatures ranging from $10^{\circ} \mathrm{C}$ to $25^{\circ} \mathrm{C}$ when the primary steam temperature is $70^{\circ} \mathrm{C}$. The maximum COP could achieve 0.59 when $T_{S}=25^{\circ} \mathrm{C}$. The minimum COP yielded 0.09 when $T_{S}=10^{\circ} \mathrm{C}$. The COP when $T_{s}=25^{\circ} \mathrm{C}$ was much higher than when $T_{s}=10^{\circ} \mathrm{C}$. It is evident that the COP increases dramatically when the secondary steam temperature increases. As shown in Figure 7, the critical condensation temperature, when $T_{S}=25^{\circ} \mathrm{C}$, is a little higher than when $T_{S}=10^{\circ} \mathrm{C}$. The difference between the 
critical condensation temperatures in these two cases is about $3{ }^{\circ} \mathrm{C}$. Thus, it can be concluded that both the COP and critical condensation temperature increased with the increase of the secondary steam temperature based on the above analysis.

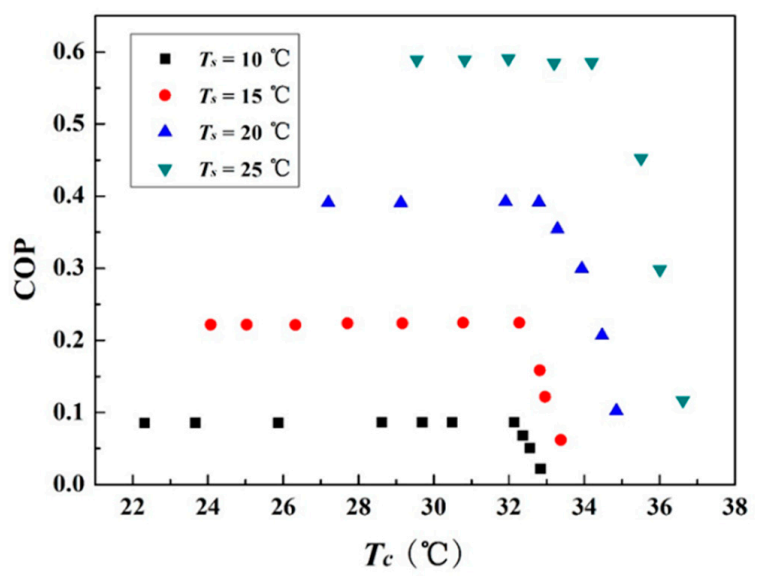

Figure 7. The effect of secondary steam temperature on the COP of the steam ejector.

To further investigate the influence of working conditions on the steam ejector, 28 experiments were carried out under primary steam temperatures ranging from $40{ }^{\circ} \mathrm{C}$ to $70{ }^{\circ} \mathrm{C}$, and the secondary steam temperature was set at $25^{\circ} \mathrm{C}, 20^{\circ} \mathrm{C}, 15^{\circ} \mathrm{C}$ and $10{ }^{\circ} \mathrm{C}$, in that order. Based on the above experimental data, a performance map showed in Figure 8 was constructed from data taken under critical condenser pressure conditions. A noticeably higher COP of the steam ejector was achieved by decreasing the primary steam temperature and increasing the secondary steam temperature. As shown in Figure 8, the maximum steam ejector COP is 2.64 when $T_{p}=40^{\circ} \mathrm{C}$ and $T_{s}=25^{\circ} \mathrm{C}$. In addition, it can be found that the secondary steam temperature has less effect on the critical condensation temperature as the primary steam temperature increases. For example, the maximum difference between the critical condensation temperatures is about $3{ }^{\circ} \mathrm{C}$ at $T_{p}=70^{\circ} \mathrm{C}$. However, the maximum difference is about $9{ }^{\circ} \mathrm{C}$ at $T_{p}=40^{\circ} \mathrm{C}$. It is important to note that the critical condensation temperature is above the secondary steam temperature when $T_{p}=40^{\circ} \mathrm{C}$ and $T_{s}=10^{\circ} \mathrm{C}$. This means that the steam ejector in the S-TVC desalination system can be powered by an extra low-temperature heat source, which is beneficial for saving energy and reducing scale. In addition, the off-design performance of the steam ejector can be predicted from Figure 8. This is very helpful for the actual operation of the system.

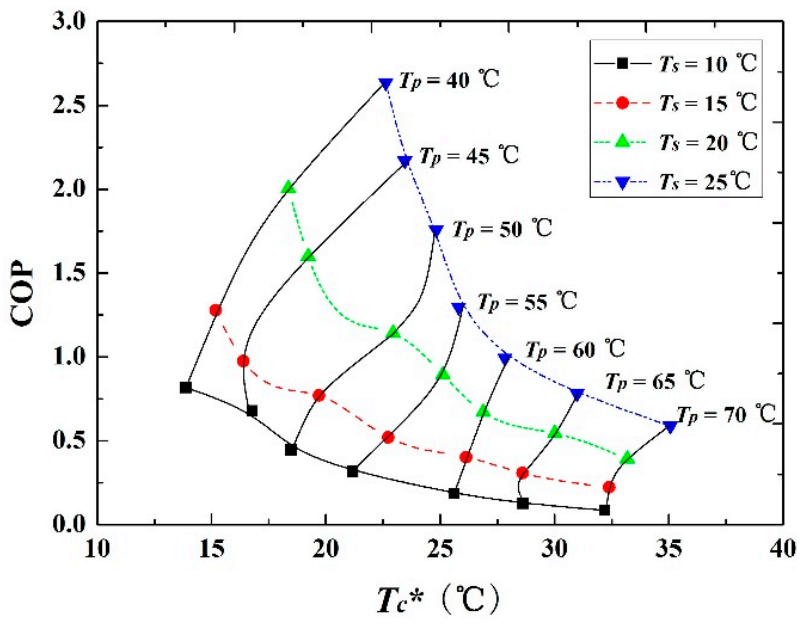

Figure 8. Performance map of the experimental steam ejector. 
When the nozzle is set at a different position in the mixing chamber, the cross-section formed between the mixing chamber and the nozzle exit will change. This directly affects the mass flow rate of the secondary steam entrained by the primary steam and has a significant impact on the performance. To investigate the influence of the NXP on the steam ejector, a movable nozzle mechanism was designed and fabricated as shown in Figure 4. The NXP is defined as zero when the nozzle exit is set at the inlet of the mixing chamber. The experiments were conducted at three different positions of $\mathrm{NXP}=50 \mathrm{~mm}, \mathrm{NXP}=100 \mathrm{~mm}$ and NXP $=150 \mathrm{~mm}$. Figure 9 shows the NXP effect on the COP and critical condensation temperature for Ejector 1 with primary steam temperatures ranging from $40^{\circ} \mathrm{C}$ to $70{ }^{\circ} \mathrm{C}$ and the secondary steam temperature set at $25^{\circ} \mathrm{C}$. The experimental results of the steam ejector with different NXPs were compared at the same primary steam temperature. The COP of the steam ejector when NXP $=100 \mathrm{~mm}$ was much higher than when NXP $=50 \mathrm{~mm}$ or NXP $=150 \mathrm{~mm}$. This means that there is an optimum NXP for the maximum COP of the steam ejector when the NXP ranges from $50 \mathrm{~mm}$ to $150 \mathrm{~mm}$, which should be investigated further in future research. It is also noted that the COP decreases as the primary steam temperature increases at a given NXP. Moreover, the results indicate that the critical condensation temperature when the NXP $=50 \mathrm{~mm}$ is lower than that when $\mathrm{NXP}=100 \mathrm{~mm}$ or NXP $=150 \mathrm{~mm}$ in most cases, as shown in Figure 9. The distinction of the critical condensation temperature between NXP $=100 \mathrm{~mm}$ and NXP $=150 \mathrm{~mm}$ is not obvious. Considering the COP and the critical condensation temperature for each NXP under the same condition, the steam ejector has a superior performance when NXP $=100 \mathrm{~mm}$ compared to the other two positions.

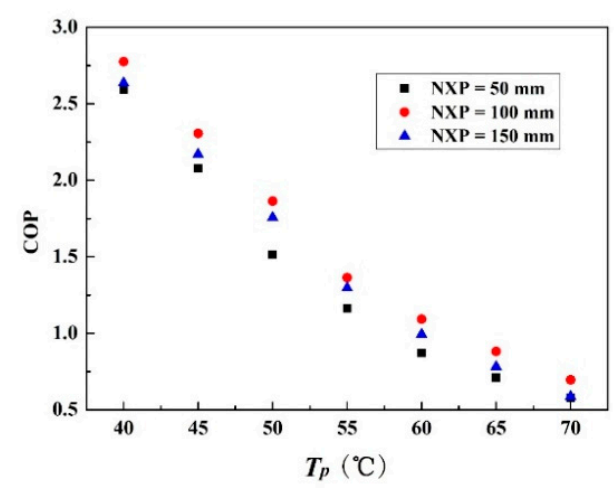

(a)

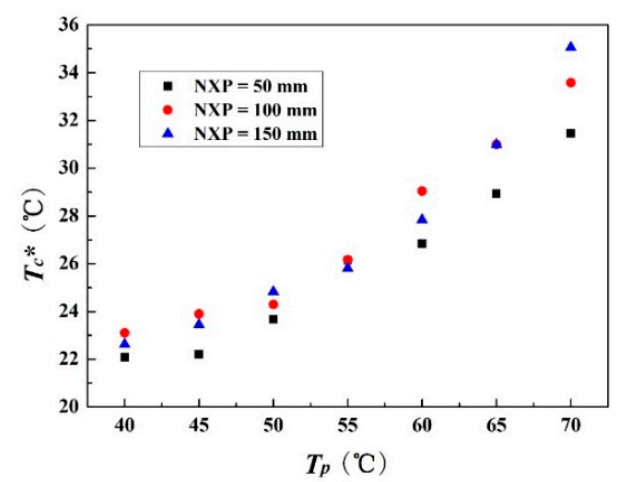

(b)

Figure 9. NXP effect on the COP and critical condensation temperature for Ejector 1; (a) Coefficient of performance (COP); (b) Critical condensation temperature.

The AR is another very important geometrical parameter, which is defined as the ratio of the area of the constant area section to the area of the nozzle throat. The AR affects the COP and the critical condensation temperature. Constant area sections with two diameters as shown in Figure 4 were designed and fabricated. Moreover, the ARs of the experimental steam ejector were 9 and 6.25, which corresponded to Ejector 1 and Ejector 2, respectively. The effects of the AR on the COP and critical condensation temperature were investigated when the primary steam temperature ranged from $40{ }^{\circ} \mathrm{C}$ to $70{ }^{\circ} \mathrm{C}$, and the secondary steam temperature was $25^{\circ} \mathrm{C}$. All of the experimental results are shown in Figure 10 (see Appendix A for detailed data). Figure 10 compares the results of the COP and the critical condensation temperature for the steam ejectors with different ARs at NXP $=50 \mathrm{~mm}$, $\mathrm{NXP}=100 \mathrm{~mm}$ and NXP $=150 \mathrm{~mm}$, in that order. As Figure 10 shows, the COP of the steam ejector when $\mathrm{AR}=9$ is higher than that of the steam ejector where $\mathrm{AR}=6.25 \mathrm{in}$ all cases. The maximum difference between the COPs of the two steam ejectors was 1.29 when the NXP was $100 \mathrm{~mm}$ and the primary steam temperature was $40^{\circ} \mathrm{C}$. In addition, the minimum difference between the COPs of the two steam ejectors was 0.25 , when the NXP was $150 \mathrm{~mm}$ and the primary steam temperature was $70{ }^{\circ} \mathrm{C}$. Furthermore, the COP of the steam ejector where AR $=6.25$ was 0.04 when the NXP was $50 \mathrm{~mm}$, and the 
primary steam temperature was $70^{\circ} \mathrm{C}$. Figure 10 shows that the COP of the steam ejector decreases as the AR decreases. Similarly, the critical condensation temperature of the steam ejector where AR $=6.25$ was higher than that of the steam ejector where $A R=9$ in most cases. The differences between the two steam ejectors are different at NXP $=50 \mathrm{~mm}, \mathrm{NXP}=100 \mathrm{~mm}$, and NXP $=150 \mathrm{~mm}$, as shown in Figure 10. When NXP $=50 \mathrm{~mm}$, the difference between the two steam ejectors was the smallest, typically by about $1^{\circ} \mathrm{C}$. The difference between the two steam ejectors was the largest when NXP $=150$ $\mathrm{mm}$. The maximum difference value was $4.6^{\circ} \mathrm{C}$ when $T_{p}=65^{\circ} \mathrm{C}$. According to this analysis, reducing the AR could help to raise the critical condensation temperature, which was affected by the NXP. The AR had an opposite effect on the COP and the critical condensation temperature. Therefore, the comparison of the performance of the two steam ejectors should be based on the relationship between the COP and the critical condensation temperature. They had a relationship of restricting each other. According to experimental results shown in Figure 10, the performance of the steam ejector where $\mathrm{AR}=9$ shows an advantage over that of a steam ejector where $\mathrm{AR}=6.25$ when the NXPs were $50 \mathrm{~mm}$ and $100 \mathrm{~mm}$. When the NXP was $150 \mathrm{~mm}$, the differences in the critical condensation temperatures between the two steam ejectors were obvious with the primary steam temperature ranging from $40^{\circ} \mathrm{C}$ to $70{ }^{\circ} \mathrm{C}$. When the primary steam temperature ranged from $40{ }^{\circ} \mathrm{C}$ to $50{ }^{\circ} \mathrm{C}$, the difference in the critical condensation temperature between the two steam ejectors was about $1{ }^{\circ} \mathrm{C}$. Although the COP difference between the two steam ejectors was obvious, the steam ejector performance where $\mathrm{AR}=9$ was superior to that of the steam ejector where $A R=6.25$ when the primary steam temperature ranged from $40^{\circ} \mathrm{C}$ to $50^{\circ} \mathrm{C}$, and NXP was $150 \mathrm{~mm}$. When the primary steam temperature ranged from $60^{\circ} \mathrm{C}$ to $70^{\circ} \mathrm{C}$, the difference in the critical condensation temperature between the two steam ejectors was greater than $4{ }^{\circ} \mathrm{C}$. However, the COP difference between the two steam ejectors decreased when the primary steam temperature increased. We determined that the performance of the steam ejector when $\mathrm{AR}=6.5$ was superior to that of the steam ejector when $\mathrm{AR}=9$, as the primary steam temperature ranged from $60^{\circ} \mathrm{C}$ to $70^{\circ} \mathrm{C}$, and the NXP was $150 \mathrm{~mm}$.
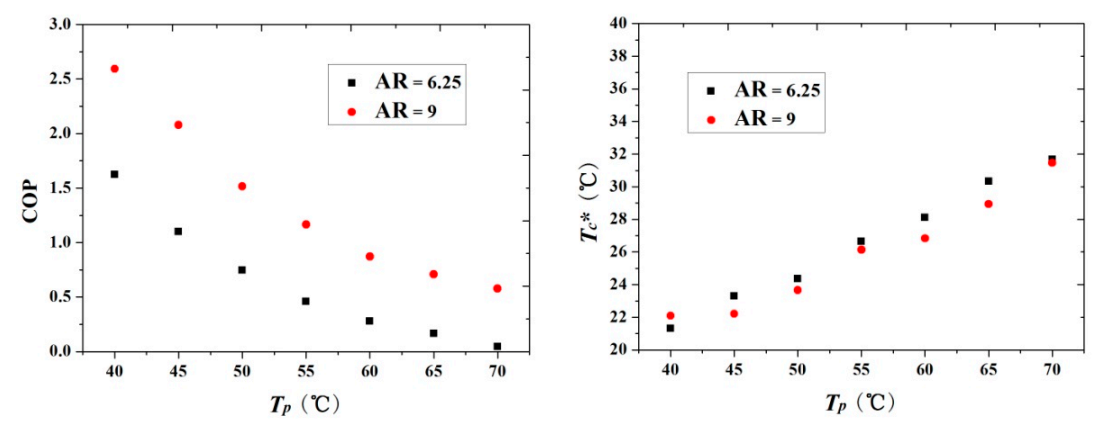

(a)
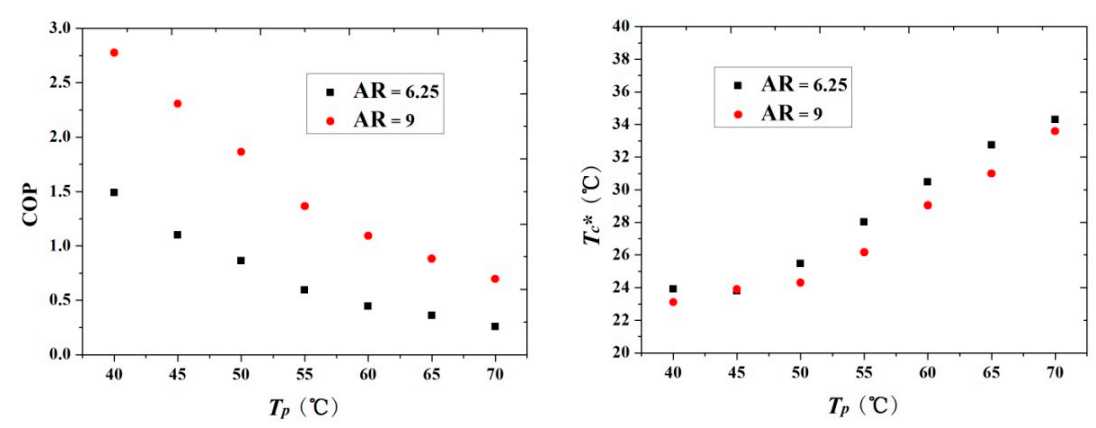

(b)

Figure 10. Cont. 

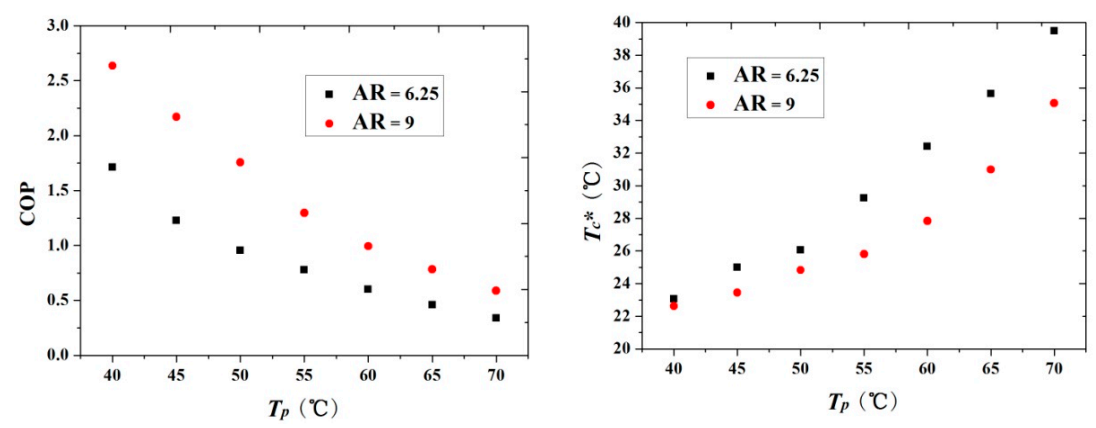

(c)

Figure 10. AR effect on the COP and critical condensation temperature at different NXPs; (a) NXP = 50 mm; (b) $\mathrm{NXP}=100 \mathrm{~mm}$; (c) NXP = $150 \mathrm{~mm}$. AR: area ratio of the ejector.

\section{Conclusions}

The paper presents an experimental investigation of a steam ejector in an S-TVC desalination system driven by a low-temperature heat source. The effects of the operating temperatures, NXP, and $\mathrm{AR}$, on the performance of the steam ejector were investigated at the primary steam temperatures ranging from $40{ }^{\circ} \mathrm{C}$ to $70{ }^{\circ} \mathrm{C}$, and the secondary steam temperatures ranging from $10{ }^{\circ} \mathrm{C}$ to $25^{\circ} \mathrm{C}$, respectively. According to the experimental results, the steam ejector can operate in the S-TVC desalination system driven by a low-temperature heat source below $100^{\circ} \mathrm{C}$. It was found that increasing the primary steam temperature could result in worse COP, but the system could function at a higher critical condensation temperature. Increasing the secondary steam temperature could improve the $\mathrm{COP}$ and the critical condensation temperature. In addition, the steam ejector has a better performance when NXP $=100 \mathrm{~mm}$ than when NXP $=50 \mathrm{~mm}$ or when NXP $=150 \mathrm{~mm}$ at $T_{p}=40-70{ }^{\circ} \mathrm{C}$, and $T_{s}=25^{\circ} \mathrm{C}$ for a given ejector. There must be an optimum NXP in the steam ejector, which should be investigated further. The COP of the steam ejector increased when the AR increased. The AR had a different effect on the critical condensation temperature when NXP $=50 \mathrm{~mm}, \mathrm{NXP}=100 \mathrm{~mm}$, and NXP $=150 \mathrm{~mm}$. Finally, the experimental results indicated that the critical condensation temperature could be increased by decreasing the AR, resulting in a dramatic COP decrease, especially when NXP $=50 \mathrm{~mm}$.

Author Contributions: J.D. and H.M. conceived and designed the experiment. J.D., W.W. and Z.H. carried out the experiment. J.D., W.W. and H.M. participated in the writing of the initial manuscript. Z.H., Y.D., F.S. and X.P. revised the manuscript and adjusted the data presentation. All authors have read and approved the manuscript.

Funding: This research was funded by the National Natural Science Foundation of China grant number 51409034, the Natural Science Foundation of Liaoning Province grant number 2014025013, and the Fundamental Research Funds for the Central Universities grant number 3132016337.

Conflicts of Interest: The authors declare no conflict of interest.

\section{Nomenclature}

$\begin{array}{ll}\text { A } & \text { area }\left(\mathrm{m}^{2}\right) \\ \text { AD } & \text { adsorption desalination } \\ \text { AR } & \text { area ratio of the ejector, } \frac{A_{c a s}}{A_{t}} \\ \text { COP } & \text { coefficient of performance } \\ d & \text { diameter }(\mathrm{mm}) \\ \text { I } & \text { current }(\mathrm{A}) \\ \text { L } & \text { length }(\mathrm{mm}) \\ \text { M } & \text { mass flow rate }(\mathrm{kg} / \mathrm{s}) \\ \text { MED } & \text { multi-effect distillation } \\ \text { NXP } & \text { nozzle exit position } \\ \text { P } & \text { pressure }(\mathrm{kPa}) \\ \text { S-TVC } & \text { single-effect thermal vapor compression }\end{array}$




$\begin{array}{ll}\text { T } & \text { temperature }\left({ }^{\circ} \mathrm{C}\right) \\ \text { TVC } & \text { thermal vapor compression } \\ \text { V } & \text { voltage }(\mathrm{V}) \\ \text { Subscripts } & \\ b & \text { brine } \\ c & \text { condition at condenser } \\ d & \text { condition at diffuser } \\ d w & \text { distilled water } \\ c a s & \text { condition at constant area section } \\ c w & \text { cooling water } \\ f & \text { feed seawater } \\ m & \text { condition at mixing chamber } \\ p & \text { condition at primary evaporator } \\ s & \text { condition at secondary evaporator } \\ t & \text { condition at nozzle throat } \\ * & \text { critical conditions }\end{array}$

\section{Appendix A}

\begin{tabular}{|c|c|c|c|c|}
\hline $\begin{array}{l}\text { Detailed Data for the AR Effect on the COP and Critical } \\
\text { Condensation Temperature at Different NXPs; NXP = } 50 \mathrm{~mm} \text {; } \\
\text { NXP = } 100 \mathrm{~mm} ; \mathrm{NXP}=150 \mathrm{~mm} . \mathrm{NXP}(\mathrm{mm})\end{array}$ & AR & $T_{p}\left({ }^{\circ} \mathrm{C}\right)$ & COP & $T_{c}{ }^{*}\left({ }^{\circ} \mathrm{C}\right)$ \\
\hline \multirow{14}{*}{50} & \multirow{7}{*}{6.25} & 40 & 1.62 & 21.3 \\
\hline & & 45 & 1.10 & 23.3 \\
\hline & & 50 & 0.75 & 24.4 \\
\hline & & 55 & 0.46 & 26.6 \\
\hline & & 60 & 0.28 & 28.1 \\
\hline & & 65 & 0.17 & 30.3 \\
\hline & & 70 & 0.04 & 31.7 \\
\hline & \multirow{7}{*}{9} & 40 & 2.59 & 22.1 \\
\hline & & 45 & 2.08 & 22.2 \\
\hline & & 50 & 1.52 & 23.7 \\
\hline & & 55 & 1.16 & 26.1 \\
\hline & & 60 & 0.87 & 26.8 \\
\hline & & 65 & 0.71 & 28.9 \\
\hline & & 70 & 0.58 & 31.5 \\
\hline \multirow{14}{*}{100} & \multirow{7}{*}{6.25} & 40 & 1.49 & 23.9 \\
\hline & & 45 & 1.10 & 23.8 \\
\hline & & 50 & 0.86 & 25.5 \\
\hline & & 55 & 0.59 & 28.0 \\
\hline & & 60 & 0.45 & 30.5 \\
\hline & & 65 & 0.36 & 32.7 \\
\hline & & 70 & 0.26 & 34.3 \\
\hline & \multirow{7}{*}{9} & 40 & 2.78 & 23.1 \\
\hline & & 45 & 2.31 & 23.9 \\
\hline & & 50 & 1.86 & 24.3 \\
\hline & & 55 & 1.36 & 26.2 \\
\hline & & 60 & 1.09 & 29.0 \\
\hline & & 65 & 0.88 & 31.0 \\
\hline & & 70 & 0.69 & 33.6 \\
\hline \multirow{14}{*}{150} & \multirow{7}{*}{6.25} & 40 & 1.71 & 23.1 \\
\hline & & 45 & 1.23 & 25.0 \\
\hline & & 50 & 0.96 & 26.0 \\
\hline & & 55 & 0.78 & 29.2 \\
\hline & & 60 & 0.60 & 32.3 \\
\hline & & 65 & 0.46 & 35.6 \\
\hline & & 70 & 0.34 & 39.5 \\
\hline & \multirow{7}{*}{9} & 40 & 2.64 & 22.6 \\
\hline & & 45 & 2.17 & 23.4 \\
\hline & & 50 & 1.76 & 24.8 \\
\hline & & 55 & 1.29 & 25.8 \\
\hline & & 60 & 0.99 & 27.8 \\
\hline & & 65 & 0.78 & 31.0 \\
\hline & & 70 & 0.59 & 35.1 \\
\hline
\end{tabular}

COP: coefficient of performance; AR: area ratio of the ejector; NXP: nozzle exit position. 


\section{References}

1. Zheng, Z.; Li, F.; Li, Q.; Wang, L.; Cai, W.; Li, X.; Zhang, H. State-of-the-art of R\&D on seawater desalination technology. Chin. Sci. Bull. 2016, 61, 2344-2370.

2. Shahzad, M.W.; Burhan, M.; Ang, L.; Ng, K.C. Energy-water-environment nexus underpinning future desalination sustainability. Desalination 2017, 413, 52-64. [CrossRef]

3. Alsaman, A.S.; Askalany, A.A.; Harby, K.; Ahmed, M.S. Performance evaluation of a solar-driven adsorption desalination-cooling system. Energy 2017, 128, 196-207. [CrossRef]

4. Youssef, P.G.; Mahmoud, S.M.; AL-Dadah, R.K. Performance analysis of four bed adsorption water desalination/refrigeration system, comparison of AQSOA-Z02 to silica-gel. Desalination 2015, 375, 100-107. [CrossRef]

5. Al-Ansari, A.; Ettouney, H.; El-Dessouky, H. Water-zeolite adsorption heat pump combined with single effect evaporation desalination process. Renew. Energy 2001, 24, 91-111. [CrossRef]

6. Zejli, D.; Benchrifa, R.; Bennouna, A.; Bouhelal, O.K. A solar adsorption desalination device: First simulation results. Desalination 2004, 168, 127-135. [CrossRef]

7. Thu, K.; Ng, K.C.; Saha, B.B.; Chakraborty, A.; Koyama, S. Operational strategy of adsorption desalination systems. Int. J. Heat Mass Transf. 2009, 52, 1811-1816. [CrossRef]

8. Thu, K.; Kim, Y.; Shahzad, M.W.; Saththasivam, J.; Ng, K.C. Performance investigation of an advanced multi-effect adsorption desalination (MEAD) cycle. Appl. Energy 2015, 159, 469-477. [CrossRef]

9. Kim, Y.; Thu, K.; Ng, K.C. Adsorption characteristics of water vapor on ferroaluminophosphate for desalination cycle. Desalination 2014, 344, 350-356. [CrossRef]

10. Ng, K.C.; Thu, K.; Kim, Y.; Chakraborty, A.; Amy, G. Adsorption desalination: An emerging low-cost thermal desalination method. Desalination 2013, 308, 161-179. [CrossRef]

11. Thu, K.; Yanagi, H.; Saha, B.B.; Ng, K.C. Performance analysis of a low-temperature waste heat-driven adsorption desalination prototype. Int. J. Heat Mass Transf. 2013, 65, 662-669. [CrossRef]

12. Ng, K.C.; Thu, K.; Saha, B.B.; Chakraborty, A. Study on a waste heat-driven adsorption cooling cum desalination cycle. Int. J. Refrig. 2012, 35, 685-693. [CrossRef]

13. Al-Juwayhel, F.; El-Dessouky, H.; Ettouney, H. Analysis of single-effect evaporator desalination systems combined with vapor compression heat pumps. Desalination 1997, 114, 253-275. [CrossRef]

14. Ettouney, H.E.H. Single-Effect Thermal Vapor-Compression Desalination Process: Thermal Analysis. Heat Transf. Eng. 1999, 20, 52-68. [CrossRef]

15. Ji, J.G.; Wang, R.Z.; Li, L.X.; Ni, H. Simulation and Analysis of a Single-Effect Thermal Vapor-Compression Desalination System at Variable Operation Conditions. Chem. Eng. Technol. 2007, 30, 1633-1641. [CrossRef]

16. Pilipovik, V.; Riverol, C. Forecasting the effect of seasonal parameters on fouling deposition: A single effect thermal-vapor compression desalination unit as study case. Desalin. Water Treat. 2012, 39, 52-54. [CrossRef]

17. Sharifi, N.; Sharifi, M. Reducing energy consumption of a steam ejector through experimental optimization of the nozzle geometry. Energy 2014, 66, 860-867. [CrossRef]

18. Wu, H.; Liu, Z.; Han, B.; Li, Y. Numerical investigation of the influences of mixing chamber geometries on steam ejector performance. Desalination 2014, 353, 15-20. [CrossRef]

19. Han, B.; Liu, Z.; Wu, H.; Li, Y. Influence of Suction Position of Thermal Vapor Compressor on Multi-effect Distillation Desalination System Performance. J. Beijing Univ. Technol. 2015, 41, 926-932.

20. Fu, W.; Li, Y.; Liu, Z.; Wu, H.; Wu, T. Numerical study for the influences of primary nozzle on steam ejector performance. Appl. Therm. Eng. 2016, 106, 1148-1156. [CrossRef]

21. Tang, Y.; Liu, Z.; Li, Y.; Shi, C.; Wu, H. Performance improvement of steam ejectors under designed parameters with auxiliary entrainment and structure optimization for high energy efficiency. Energy Convers. Manag. 2017, 153, 12-21. [CrossRef]

22. Tang, Y.; Li, Y.; Liu, Z.; Wu, H.; Fu, W. A novel steam ejector with auxiliary entrainment for energy conservation and performance optimization. Energy Convers. Manag. 2017, 148, 210-221. [CrossRef]

23. Tang, Y.; Liu, Z.; Li, Y.; Shi, C. Combined auxiliary entrainment and structure optimization for performance improvement of steam ejector with consideration of back pressure variation. Energy Convers. Manag. 2018, 166, 163-173. [CrossRef]

24. Wang, C.; Wang, L.; Zou, T.; Zhang, H. Influences of area ratio and surface roughness on homogeneous condensation in ejector primary nozzle. Energy Convers. Manag. 2017, 149, 168-174. [CrossRef] 
25. Wang, C.; Wang, L.; Zhao, H.; Du, Z.; Ding, Z. Effects of superheated steam on non-equilibrium condensation in ejector primary nozzle. Int. J. Refrig. 2016, 67, 214-226. [CrossRef]

26. Liu, J.; Wang, L.; Jia, L.; Wang, X. The influence of the area ratio on ejector efficiencies in the MED-TVC desalination system. Desalination 2017, 413, 168-175. [CrossRef]

27. Liu, X.; Liu, Z. Numerical investigation and improvement strategy of flow characteristics inside supersonic separator. Sep. Sci. Technol. 2018, 53, 940-952. [CrossRef]

28. Ji, M.; Utomo, T.; Woo, J.; Lee, Y.; Jeong, H.; Chung, H. CFD investigation on the flow structure inside thermo vapor compressor. Energy 2010, 35, 2694-2702. [CrossRef]

29. Li, Y.; Hu, E.; Wu, J.W.; Biggs, M.J. Recent Progress of Research and Development of Adsorption Desalination. J. Chem. Eng. Jpn. 2014, 47, 303-308. [CrossRef]

(C) 2018 by the authors. Licensee MDPI, Basel, Switzerland. This article is an open access article distributed under the terms and conditions of the Creative Commons Attribution (CC BY) license (http:/ / creativecommons.org/licenses/by/4.0/). 